\title{
Seed burial in eelgrass Zostera marina: the role of infauna
}

\author{
Natalia J. Blackburn*, Robert J. Orth \\ Virginia Institute of Marine Science, College of William and Mary, PO Box 1346, Gloucester Point, Virginia 23062, USA
}

\begin{abstract}
Seed burial is a vital process that influences small- and large-scale plant population patterns and is frequently mediated by soil-dwelling invertebrates. Despite its importance in terrestrial systems, very little is known about seed burial in seagrasses. The goal of this work was to determine the role that benthic infauna play in the burial of Zostera marina seeds. Mesocosm experiments studying seed burial depth, seed burial rate, and particle burial and redistribution using beads, were conducted in defaunated sediment cores populated with single specimens of infauna with different modes of feeding and thus bioturbation effects: Amphitrite ornata (downward conveyor deposit feeder), Clymenella torquata and Pectinaria gouldi (upward conveyor deposit feeders), and Neanthes succinea (gallery biodiffuser). Seeds and beads in animal cores were significantly more likely to be buried than seeds in control cores in each experiment, although burial depths and rates varied by species. $N$. succinea and $P$. gouldi showed the most dramatic burial. N. succinea also showed evidence for actively burying seeds. Seed burial depths for A. ornata, C. torquata, and P. gouldi related well to individual bioturbation rates for those species. These results indicate that $Z$. marina seed burial is facilitated by infaunal bioturbation. Further, individual species have a different impact on burial patterns, and burial is rapid and occurs within days. Seed burial by infaunal bioturbation is relevant to seed survival by providing escape from predation, retention in suitable settlement sites, and movement to a sediment depth suitable for germination.
\end{abstract}

KEY WORDS: Seagrass $\cdot$ Chesapeake Bay $\cdot$ Bioturbation $\cdot$ Polychaete $\cdot$ Mesocosm

\section{INTRODUCTION}

In terrestrial systems, seed burial has been shown to influence both small- and large-scale population patterns of adult plants (Warr et al. 1993), as well as species invasion dynamics and the intensity of interspecific competition (Regnier et al. 2008). There are 3 major categories of burial processes: burial by abiotic processes, such as wind or rain (Benvenuti 2007), seed-mediated burial (Chambers et al. 1991), and burial by other organisms (Chambers \& MacMahon 1994). In the terrestrial literature, seed burial by other organisms has been shown to be the most universally important seed burial process (Chambers \& MacMahon 1994).
While vertebrates have a clear role in seed burial in terrestrial systems, e.g. birds and rodents caching large seeds (Beck \& Vander Wall 2010, Haugaasen et al. 2010), invertebrates, especially ants (Hughes \& Westoby 1992, Lengyel et al. 2010, Renard et al. 2010) and earthworms (Darwin 1881, Vanderreest \& Rogaar 1988, Willems \& Huijsmans 1994, Eisenhauer et al. 2008), influence the burial of a much wider variety of seed shapes and sizes, and in some species at a rate more rapidly than abiotic processes (Regnier et al. 2008). However, little is known about seed burial in aquatic plants in general (Koch et al. 2010), and even less in marine angiosperms, or seagrasses. Seagrasses diverged from their terrestrial ancestors 100 million years ago (Orth et al. 2006), and, like other 
angiosperms, they flower and produce seeds. These seeds, many of which are initially dispersed primarily by abiotic mechanisms (Kendrick et al. 2012), are negatively buoyant, and settle rapidly to the sediment surface where they become incorporated into the sediment matrix and germinate (Orth et al. 1994). While precise mechanisms for burial are poorly understood, some marine benthic infauna are capable of significant sediment reworking and particle redistribution, which has the potential to influence seed burial dynamics (Lohrer et al. 2005, Quintana et al. 2007, Valdemarsen et al. 2011, Delefosse \& Kristensen 2012, Kristensen et al. 2012).

Eelgrass Zostera marina is a seagrass found in northern temperate oceans throughout the world (Green \& Short 2003). In the Chesapeake Bay region, $Z$. marina flowers and produces seeds in May and June. Seedling establishment patterns in the field indicate that the seeds do not move far once they settle to the sediment surface (Orth et al. 1994), which implies that they are quickly buried. Burial is important for successful seedling establishment because it reduces seed predation by blue crabs (Fishman \& Orth 1996), places seeds in an appropriate germination environment (Moore et al. 1993), and reduces the chance that the seedlings will get washed away by winter storms (Marion \& Orth 2012).

Despite the clear importance of seed burial to the germination and establishment of Zostera marina, very little work has been done to determine how its seeds are buried. It is likely that burial is mediated in part by abiotic processes, such as sedimentation and sand ripple migration, but, as in terrestrial systems, burial is probably influenced or augmented by the animals living in the sediment. Valdemarsen et al. (2011) concluded that bioturbation by the arenicolid polychaete Arenicola marina inhibits $Z$. marina recovery by burying seeds too deeply for successful germination. Delefosse \& Kristensen (2012) concluded that various polychaete species' burial effects can have both positive and negative effects on seeds depending on their particular feeding mode. Luckenbach \& Orth (1999) showed that Z. marina seeds moving through a flume are retained near the burial mounds of the maldanid polychaete Clymenella torquata, and this retention increases with worm density. Harwell \& Orth (2001) found that the onuphid polychaete Diopatra cuprea can influence seed dispersal by attaching flowering shoots to its tube cap, which results in the seeds being deposited near the tube. Some work has been done on seed retention in marsh species and freshwater submersed aquatic vegetation (see Chang et al. 2008 and Koch et al. 2010), but neither study addressed seed burial.

The goal of this study was to better understand what role marine infauna play in Zostera marina seed burial. The following questions were addressed: (1) Are seeds deposited on sediments containing infauna buried more quickly and deeply than sediments without infauna? (2) Does the infaunal bioturbation mode such as downward or upward conveyor affect seed burial depth?

\section{MATERIALS AND METHODS}

\section{Seed collection, storage, and viability assessment}

Flowering shoots with mature Zostera marina seeds were harvested from an established meadow in South Bay ( $\left.37^{\circ} 16^{\prime} 20^{\prime \prime} \mathrm{N}, 75^{\circ} 48^{\prime} 51^{\prime \prime} \mathrm{W}\right)$, a coastal bay located in the US mid-Atlantic region near the southern limits of this species. Seeds were removed from the flowering shoot material and held in a recirculating seawater system as described by Marion \& Orth (2010) until the initiation of each experiment. Seeds are oval and approximately $3.0 \mathrm{~mm}$ long and $1.3 \mathrm{~mm}$ wide, with a mass of $3.6 \mathrm{mg}$ (Orth et al. 1994).

\section{Animal collection}

The animals used in these experiments were locally common polychaete representatives (Wass 1972) of 3 major functional groups of bioturbators (Kristensen et al. 2012). Amphitrite ornata is a sessile 'downward conveyor' deposit feeder which constructs a U-shaped tube up to $60 \mathrm{~cm}$ in length and protruding from the sediment at either end. A. ornata uses tentacles to selectively transport sediment to the mouth. Manipulated but non-ingested material forms a conical deposit around the anterior end of the tube, and defecated material forms a conical deposit around the posterior end of the tube. Clymenella torquata is a sessile 'upward conveyor' deposit feeder which builds a 10 to $20 \mathrm{~cm}$ long tube perpendicular to the sediment surface. C. torquata ingests sediment at depth and defecates on the sediment surface, creating a defecation mound around the tube opening. Pectinaria gouldi is another 'upward conveyor' deposit feeder which builds a 4 to $6 \mathrm{~cm}$ long tube oblique to the sediment surface. In addition to acting as a conveyer belt species, $P$. gouldi moves laterally through the sediment, dragging its tube with it. Neanthes succinea is an errant omnivore which cre- 
ates a gallery of mucus-lined burrows 6 to $7 \mathrm{~cm}$ deep (N. J. Blackburn pers. obs.) with numerous surface openings and is considered a 'gallery biodiffuser,' moving through and over the sediment, searching for specific large organic particles for ingestion.

Infauna were collected by sieving sediment collected by shovel or suction dredge through $1.0 \mathrm{~mm}$ mesh sieves or bags (Orth \& van Montfrans 1987). Whole, uninjured animals were carefully separated from the sediment, removed from their tubes (except Pectinaria gouldi, which we noted would not remake its tube as readily as the other polychaetes), and placed in aerated water bowls with seawater until the initiation of the experiment. At the end of each experiment, the animals were recovered, and their length and wet weight were determined.

\section{Experimental set-up}

Sediment cores were collected from a shallow, unvegetated site using $10 \mathrm{~cm}$ diameter PVC sleeves inserted to a depth of approximately $11 \mathrm{~cm}$, capped at the bottom, and transported back to the laboratory. Cores were frozen for a minimum of $1 \mathrm{wk}$ in order to eliminate macroinvertebrates without disrupting the sediment matrix. Frozen cores were placed in the experimental tank and allowed to thaw completely before a single infaunal individual was added to each non-control core. Animals were allowed to acclimate overnight and establish themselves in a natural manner so their subsequent interactions with seeds were realistic. Animals that did not rebury were replaced with new animals following the same protocol. Direct observation showed that animals rapidly reburied and were actively bioturbating within $12 \mathrm{~h}$. Amphitrite ornata, Clymenella torquata, and Pectinaria gouldi buried in the center of the core, minimizing any edge effects, while some Neanthes succinea moved laterally and constructed their burrows adjacent to the walls of the core. At the end of each experiment, the depth of each particle (seed or bead) in each core was determined by sieving. The rubber cap on the bottom of the PVC sleeve was removed and replaced with a $10 \mathrm{~cm}$ diameter disk of rigid plastic. This disk was pushed up into the sleeve to extrude the sediment in $0.5 \mathrm{~cm}$ increments. Each increment was sliced off the main core and rinsed through a $1.0 \mathrm{~mm}$ sieve, and the number of particles (seeds or beads) in each increment was recorded. Cores were sieved incrementally until all seeds or beads had been accounted for, or until the bottom of the worm's tube was reached. Then, the remaining portion of the core was sieved all at once, to verify that all seeds or beads in the core had been found during the incremental sieving.

All experiments were run in a shaded recirculating tank held at a temperature and salinity of 21 to $23^{\circ} \mathrm{C}$ and 20, respectively, simulating field conditions where the animals were collected (Wass 1972). Air was bubbled into the tank away from the cores. Flow was controlled so as to not influence the core surface, and was noted by the nearly symmetrical defecation mounds. Thus, we minimized any physical processes that could influence burial. The tank was housed in a greenhouse located at Gloucester Point, Virginia (USA). The experiments were conducted from June to August 2011.

\section{Seed burial depth experiment}

The seed burial depth experiment aimed to determine the seed burial potential of infaunal species in each of the described functional groups. Twenty cores were assigned to each of 5 treatments (Amphitrite ornata, Clymenella torquata, Neanthes succinea, Pectinaria gouldi, and a no-animal control) and randomly placed in the tank. Following this acclimation, 10 viable Zostera marina seeds were scattered on the surface of each core. Cores containing $N$. succinea were covered with fine mesh netting in order to retain the worm in the core. The experiment was terminated after $2 \mathrm{wk}$.

\section{Seed burial rate experiment}

Two separate experiments were conducted to determine the rate at which seeds were buried by different species. The first incorporated Amphitrite ornata, Clymenella torquata, Neanthes succinea, and a no-animal control, with 20 cores assigned to each treatment and randomly placed in the tank. The experiment was conducted as in the seed burial depth experiment, except that 5 cores from each treatment were sieved $1,3,7$, and $13 \mathrm{~d}$, respectively, after the addition of the seeds.

The second seed burial rate experiment incorporated only Pectinaria gouldi because only 4 P. gouldi were available. The experiment was conducted to be as comparable as possible to the seed burial rate experiment with the other infaunal species. Each of the $4 P$. gouldi was added to a core and allowed to bury. Ten Zostera marina seeds were added to the surface of those 4 cores as well as 4 control cores. All 
8 cores were sieved after $1 \mathrm{~d}$. The $P$. gouldi were then added to 4 new cores and allowed to bury. Ten $Z$. marina seeds were added to the surface of those 4 cores as well as 4 control cores. All 8 cores were sieved after $3 \mathrm{~d}$. This was repeated twice more, with sieving occurring 7 and $13 \mathrm{~d}$, respectively, after the addition of the seeds.

\section{Particle burial and redistribution experiment}

The particle burial and redistribution experiment more thoroughly explored how different species of infauna redistribute large particles in the sediment. Eighteen cores were assigned to each of 4 treatments-Amphitrite ornata, Clymenella torquata, Neanthes succinea, or a no-animal control (total of 72 cores) - and randomly placed in the tank. For 7 consecutive days, 10 small colored glass beads (size $15 / 0, \sim 1 \mathrm{~mm}$ long and $2 \mathrm{~mm}$ in diameter) were placed on the surface of each core, with a different color of bead added on each day. The beads were slightly more dense than seeds, but less dense than sediment. However, they were similar in size to seeds. We minimized the effect of density, which plays an important role in physical burial processes, with our flow-through system. We believe biotic burial is most strongly affected by particle size, so that was the aspect of Zostera marina seeds that we felt was most important to match with the beads. On Day 8, one-half of the cores from each treatment were sieved as in the seed burial experiment, and on Day 15, the remaining cores were sieved. The number and color of beads in each $0.5 \mathrm{~cm}$ increment were recorded

\section{Sediment analysis}

Sediment samples were taken from control cores at the end of the seed burial depth experiment and the seed burial rate experiment ( 2 samples per experiment to a depth of $4 \mathrm{~cm}$ ). Sediment was analyzed for percent gravel, sand, silt, clay, nitrogen, and total organic carbon. Gravel (> $2000 \mu \mathrm{m}$ ) and sand (2000 to $62.5 \mu \mathrm{m}$ ) fractions were determined by dry and wet sieving, respectively. Silt (4 to $62.5 \mu \mathrm{m}$ ) and clay $(<4 \mu \mathrm{m})$ fractions were determined by the pipette method (Folk 1980). Nitrogen and total organic carbon fractions were analyzed on an Exeter $\mathrm{CHN}$ Model $440 \mathrm{CE}$ analyzer using the methods from the Exeter Analytical Model 440 CHN/O/S Elemental Analyzer Manual, Part no. 150-000.

\section{Data analysis}

All data analysis was conducted in the R statistical package, version 2.11.1 (The R Foundation for Statistical Computing). For each core, the mean, median, and maximum particle burial depths on the last day of the experiment were calculated and averaged within treatments. For all experiments, seeds and beads were considered to be buried when they were no longer visible on the sediment surface. Mean buried seed depth $( \pm$ SD) was calculated for buried seeds only by using the center of each layer's range as the seed depth.

In the seed burial depth experiment, the proportion of seeds found below the sediment surface was calculated for each core and used in a logistic regression (Peng et al. 2002). Using the regression outputs, ratios of the probability of seed burial in each of the animal treatments versus the probability of seed burial in the control treatment were calculated. A Kruskal-Wallis test (Chan \& Walmsley 1997, all tests were considered significant at an alpha level of $\mathrm{p}<0.05$ ) was conducted on mean seed depth per core, and 2-tailed post hoc testing was used to make all possible pairwise comparisons of seed burial between treatments.

In the seed burial rate experiments, the proportion of seeds buried on each sampling day was calculated for each core and averaged within treatments. A Kruskal-Wallis test (Chan \& Walmsley 1997) was conducted on the proportion of seeds buried after 1, 3,7 , and $13 \mathrm{~d}$, and 1-tailed post hoc testing was used to compare the proportion of seeds buried in each animal treatment with the proportion of seeds buried in the control treatment.

In the particle burial and redistribution experiment, the proportion of beads buried on each sampling day was calculated for each bead color and averaged by color within treatments. A logistic regression was used to analyze the difference in the proportion of beads buried between beads representing 1 and $14 \mathrm{~d}$ of burial. A non-parametric MannWhitney rank sum test (Frick \& Rahlfs 1998), which is robust to unequal sample sizes, was used to compare the mean bead depth and mean seed depth after $13 \mathrm{~d}$ of burial for each treatment (seed data were from the seed burial rate experiment). A Kruskal-Wallis test (Chan \& Walmsley 1997) was conducted on the proportion of beads buried on Days 1, 3, 7, and 13, and 1 -tailed post hoc testing was used to compare the proportion of beads buried in each animal treatment with the proportion of beads buried in the control treatment. 


\section{RESULTS}

\section{Sediment analysis}

The sediment used in these experiments was found to be on average $0.54 \%$ gravel, $97.20 \%$ sand, $0.65 \%$ silt, and $1.62 \%$ clay. Total organic carbon was below the detection limit $(0.170 \%)$, and total nitrogen was $0.015 \%$.

\section{Faunal characteristics}

Amphitrite ornata used in these experiments ranged in length from 0.5 to $5.0 \mathrm{~cm}$ and in wet mass from 0.05 to $1.27 \mathrm{~g}$, with a mean length of $2.7 \mathrm{~cm}$ and a mean wet mass of $0.4 \mathrm{~g}$. Clymenella torquata ranged in length from 1.0 to $4.5 \mathrm{~cm}$ (mean $2.7 \mathrm{~cm}$ ) and in wet mass from 0.04 to $0.17 \mathrm{~g}$ (mean $0.2 \mathrm{~g}$ ). Neanthes succinea ranged from 2.0 to $8.5 \mathrm{~cm}$ (mean $4.7 \mathrm{~cm}$ ) and 0.10 to $0.79 \mathrm{~g}$ (mean $0.4 \mathrm{~g}$ ). Pectinaria gouldi ranged from $1.0(2.0 \mathrm{~cm}$ with tube) to $2.5 \mathrm{~cm}$ (5.5 cm with tube) in length and from 0.09 to $0.58 \mathrm{~g}$ in wet mass, with a mean length of $1.6 \mathrm{~cm}(3 \mathrm{~cm}$ with tube) and a mean wet mass of $0.3 \mathrm{~g}$. These sizes represent the range of sizes of individuals currently found in their respective habitats.

\section{Seed burial depth experiment}

Seed burial was recorded in all treatments after $2 \mathrm{wk}$, and at least some seeds remained on the sediment surface at the end of the experiment in all treatments. All animal treatments yielded deeper seed burial than the control treatment.

Median seed depth was in the $0-0.5 \mathrm{~cm}$ depth layer for all animal treatments, and the mean and maximum seed depths ranged from 0.4 to $1.0 \mathrm{~cm}$ and 1.0 to $4.5 \mathrm{~cm}$, respectively. Control cores had a median seed depth of $0.0 \mathrm{~cm}$, a mean $\pm \mathrm{SD}$ seed depth of 0.1 $\pm 0.2 \mathrm{~cm}$, and a maximum seed depth in the 0.5$1.0 \mathrm{~cm}$ depth layer (Table 1). Percent of seeds actually buried varied by species, with 67, 60, 97, and $68 \%$ of all seeds buried by Amphitrite ornata, Clymenella torquata, Neanthes succinea, and Pectinaria gouldi, respectively, with only $20 \%$ of control seeds buried (Table 1). During the experiment, there was some algal growth on the surface of the control cores, making it difficult to see seeds on the surface. The relatively high percentage buried in the controls is an artifact of this algal growth.

The depth distribution of seeds varied between species, but generally the largest fraction of seeds was found in the $0-0.5 \mathrm{~cm}$ depth interval (Fig. 1). Burial was most dramatic in both Neanthes succinea and Pectinaria gouldi cores. In N. succinea cores, 61.5, 20.5 , and $12.8 \%$ of seeds were found in the $0-0.5$, 0.5-1.0, and 1.0-1.5 cm depth intervals, respectively, with $2.6 \%$ found in the $2.5-3.0 \mathrm{~cm}$ depth interval. In $P$. gouldi cores, seeds were found in all depth intervals, with the deepest buried seeds $(3.5 \%)$ in the 4.0-4.5 cm depth interval. In N. succinea cores, seeds were frequently found inside the worm's burrow, rather than in the surrounding sediment. In all other animal cores, the seeds were never found inside the worm's tube. In control cores, $80 \%$ of seeds were found on the surface. In several of the control cores, an algal mat developed, covering the seeds and causing more seeds to be ranked as buried.

Logistic regression revealed that seeds in all animal cores had a significantly higher chance of being buried than the seeds in the control cores $(p<0.0001)$, with the odds of being buried depending on the species, but increasing by a factor of more than 6 over the control cores in all cases (Table 2).

A Kruskal-Wallis test showed the burial depth to be significantly different between all animal treatments and the control treatment. The burial depth in Pectinaria gouldi cores was significantly different than the burial depth in Clymenella torquata or Amphitrite ornata cores.

Table 1. Zostera marina. Summary of seed burial depths after 13 wk in cores $(n=10)$ with 1 worm and 10 seeds core ${ }^{-1}$. Seeds were recovered in $0.5 \mathrm{~cm}$ depth intervals, and the depth intervals containing the median seed depth and maximum seed depth are given. Mean buried seed depth ( \pm SD) was calculated for buried seeds only by using the center of each layer's range as the seed depth

\begin{tabular}{|c|c|c|c|c|c|}
\hline Treatment & $\begin{array}{c}\text { Median } \\
\text { depth interval }(\mathrm{cm})\end{array}$ & $\begin{array}{c}\text { Mean buried } \\
\text { seed depth }(\mathrm{cm})\end{array}$ & $\begin{array}{c}\text { Maximum } \\
\text { depth interval }(\mathrm{cm})\end{array}$ & $\begin{array}{l}\text { Total no. seeds } \\
\text { buried }(\%)\end{array}$ & $\begin{array}{l}\text { Total no. seeds } \\
\text { not buried }\end{array}$ \\
\hline Control & 0.0 & $0.26 \pm 0.08$ & $0.5-1.0$ & $37(20)$ & 149 \\
\hline Amphitrite ornata & $0.0-0.5$ & $0.30 \pm 0.21$ & $1.5-2.0$ & $103(67)$ & 50 \\
\hline Clymenella torquata & $0.0-0.5$ & $0.43 \pm 0.30$ & $1.0-1.5$ & $88(60)$ & 58 \\
\hline Neanthes succinea & $0.0-0.5$ & $0.55 \pm 0.51$ & $2.5-3.0$ & 38 (97) & 1 \\
\hline Pectinaria gouldi & $0.0-0.5$ & $1.27 \pm 1.18$ & $4.0-4.5$ & $116(68)$ & 55 \\
\hline
\end{tabular}



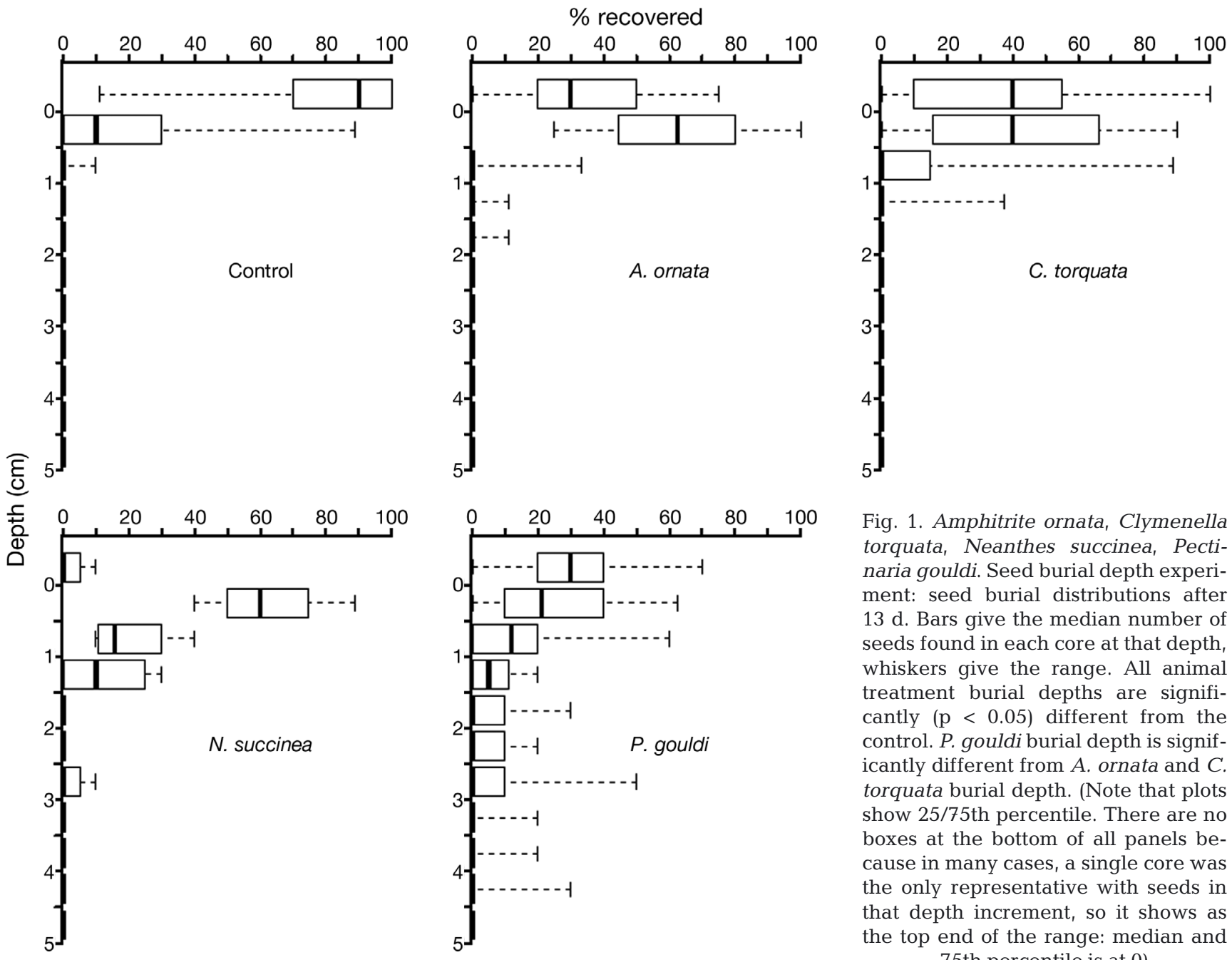

Fig. 1. Amphitrite ornata, Clymenella torquata, Neanthes succinea, Pectinaria gouldi. Seed burial depth experiment: seed burial distributions after $13 \mathrm{~d}$. Bars give the median number of seeds found in each core at that depth, whiskers give the range. All animal treatment burial depths are significantly ( $p<0.05$ ) different from the control. P. gouldi burial depth is significantly different from $A$. ornata and $C$. torquata burial depth. (Note that plots show 25/75th percentile. There are no boxes at the bottom of all panels because in many cases, a single core was the only representative with seeds in that depth increment, so it shows as the top end of the range: median and 75 th percentile is at 0 )

Table 2. Zostera marina. Seed burial depth experiment: summary of logistic regression output. Values were all significant at $p<<0.001$. Odds ratio = (probability of burial in a treatment core) / (probability of burial in a control core). For example, an odds ratio of 8.3 means that a seed is 8.3 times more likely to be buried in an Amphitrite ornata core than in a control core

\begin{tabular}{|lccc|}
\hline Treatment & Log(odds) & Odds ratio & 95\% CI of odds ratio \\
\hline Amphitrite ornata & +2.1 & 8.3 & $5.1-13.7$ \\
Clymenella torquata & +1.8 & 6.1 & $3.8-10.1$ \\
Neanthes succinea & +5.0 & 153.0 & $31.6-2760.4$ \\
Pectinaria gouldi & +2.1 & 8.5 & $5.3-13.9$ \\
\hline
\end{tabular}

cores, with control cores showing the lowest proportion of seeds buried. The proportion of seeds buried in all animal cores showed a dramatic increase over the sampling period, with $\sim 75 \%$ of seeds buried in $N$. succinea and $P$. gouldi cores and $\sim 40 \%$ of seeds buried in $A$. ornata and $C$. torquata cores at the last sampling. The control cores showed very little increase in burial, with only $\sim 5 \%$ of seeds buried at the last sampling.

\section{Seed burial rate experiments}

The proportion of seeds buried after each sampling period varied widely in the different animal cores from both experiments (Fig. 2). However, Neanthes succinea and Pectinaria gouldi cores consistently showed the greatest proportion of seeds buried followed by Amphitrite ornata and Clymenella torquata
After $13 \mathrm{~d}$, the mean \pm SD seed depth was $0.0 \pm$ $0.1 \mathrm{~cm}$ in the control cores, $0.3 \pm 0.4 \mathrm{~cm}$ in the Amphitrite ornata cores, $0.2 \pm 0.2 \mathrm{~cm}$ in the Clymenella torquata cores, $0.8 \pm 1.0 \mathrm{~cm}$ in the Neanthes succinea cores, and $1.2 \pm 1.6 \mathrm{~cm}$ in the Pectinaria gouldi cores. The median seed depth was $0.0 \mathrm{~cm}$ for control and $C$. torquata cores, and in the $0-0.5 \mathrm{~cm}$ depth interval for A. ornata, N. succinea, and P. gouldi cores. The maxi- 
mum seed depth was in the $0-0.5 \mathrm{~cm}$ depth interval for the control and $C$. torquata cores, in the $1.5-2.0 \mathrm{~cm}$ depth interval for the $A$. ornata cores, in the 4.0$4.5 \mathrm{~cm}$ depth interval for the $N$. succinea cores, and in the 6.0-6.5 cm depth interval for the P. gouldi cores.

A Kruskal-Wallis test found the proportion of seeds buried in Neanthes succinea and Pectinaria gouldi cores to be significantly higher than the proportion of seeds buried in control cores after $1 \mathrm{~d}$ of burial. After 3 d of burial, N. succinea, P. gouldi, and Clymenella torquata cores had a significantly higher proportion of seeds buried than control cores. After both 7 and $13 \mathrm{~d}$, all animal cores had a significantly higher proportion of seeds buried than control cores. Due to experimental constraints, we had too few replicates to provide sufficient power to conduct all possible pairwise comparisons between treatments. However, these experiments do support a comparison between each treatment and the control, allowing us to evaluate the speed of burial of each species.

\section{Particle burial and redistribution experiment}

All treatments showed an increase in the proportion of beads buried over the $2 \mathrm{wk}$ experiment (Fig. 3). The proportion of beads buried in the animal cores increased throughout the experiment, while the proportion of beads buried in the control cores remained near 0 , but varied by up to about $10 \% \mathrm{~d}^{-1}$. At the first sampling, on Day 8, the data represented burial of beads after $1,2, \ldots$, through $7 \mathrm{~d}$, respectively. After $1 \mathrm{~d}$, Amphitrite ornata, Clymenella torquata, and Neanthes succinea cores had an average of 4,18 , and $40 \%$ of beads buried, respectively. There was an average of $1 \%$ of beads buried in the control cores. At the second sampling, on Day 15, the data represented burial of beads after $8,9, \ldots$, through $14 \mathrm{~d}$. After $14 \mathrm{~d}, A$. ornata, C. torquata, and $N$. succinea cores had an average of 34,40 , and $50 \%$ of beads buried, respectively. Control cores had an average of $6 \%$ of beads buried.

In Neanthes succinea cores, beads were occasionally found inside the worm's burrow, rather than in the surrounding sediment. In all other animal cores, the beads were never found inside the worm's tube.

Logistic regression revealed a significant difference between the proportion of beads buried after 1 and $14 \mathrm{~d}$ in
Amphitrite ornata cores $(\mathrm{p}<0.001)$ and Clymenella torquata cores $(\mathrm{p}=0.03)$. There was no significant difference in Neanthes succinea cores $(\mathrm{p}=0.47)$ and control cores $(\mathrm{p}=0.14)$.

At the sampling on Day 15, the beads that had been placed on Day 2 represented burial after $13 \mathrm{~d}$, which was comparable to the data collected after $13 \mathrm{~d}$ in the seed burial rate experiment. After $13 \mathrm{~d}$, the mean bead depth was $0.0 \pm 0.1 \mathrm{~cm}$ in the control cores, $0.2 \pm 0.2 \mathrm{~cm}$ in the Amphitrite ornata cores, 0.2 $\pm 0.3 \mathrm{~cm}$ in the Clymenella torquata cores, and $0.4 \pm$ $0.4 \mathrm{~cm}$ in the Neanthes succinea cores. A non-parametric Mann-Whitney rank sum test showed that the mean bead depth after 13 d was not significantly different than the mean seed depth after $13 \mathrm{~d}$ for control

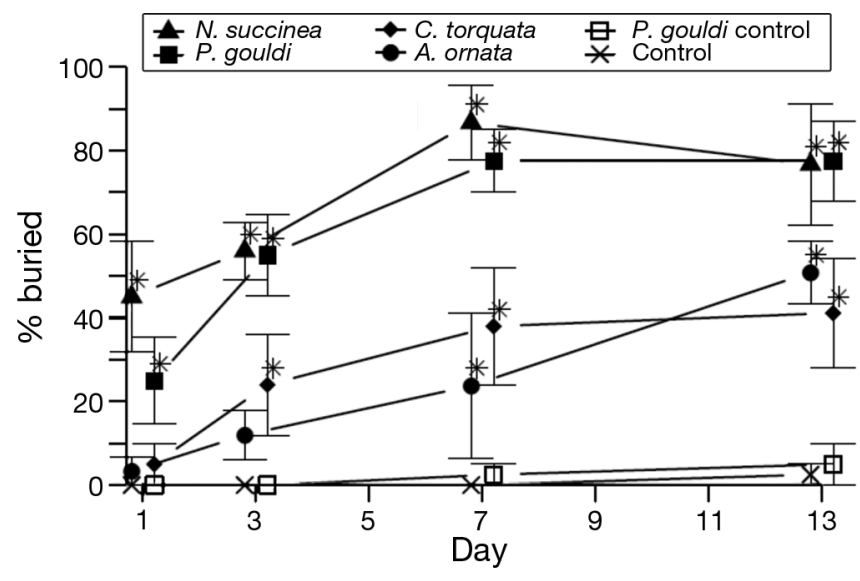

Fig. 2. Neanthes succinea, Pectinaria gouldi, Clymenella torquata, Amphitrite ornata. Seed burial rate experiment: percent of seeds buried at each sampling. Note that day corresponds to how many days the seeds were in the cores. Standard error is shown. Asterisk indicates a significant difference from the control on that day $(\mathrm{p}<0.05)$. The $P$. gouldi control is for the $P$. gouldi experiment only

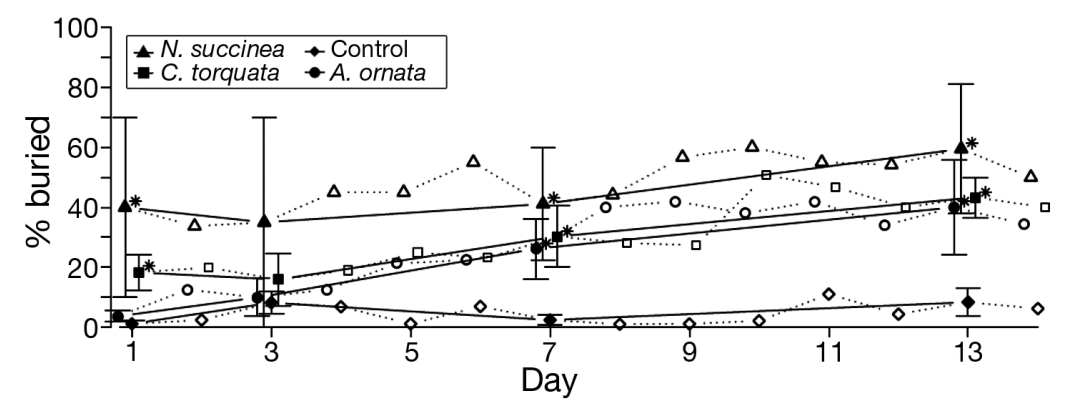

Fig. 3. Neanthes succinea, Clymenella torquata, Amphitrite ornata. Particle burial and redistribution experiment: percent of beads buried. Note that day corresponds to how many days the beads were in the cores. Sampling occurred on Days 8 and 15 (after 7 and 14 d, respectively). Solid lines show the data as if the beads had been sampled as the seeds in the seed burial rate experiment. Standard error is shown. Asterisk indicates a significant difference from the control on that day $(\mathrm{p}<0.05)$ 
cores $(p=0.626), A$. ornata cores $(p=0.13)$, or $C$. torquata cores $(p=0.52)$, but was significantly different for $N$. succinea cores $(\mathrm{p}=0.0058)$. The median bead depth was $0.0 \mathrm{~cm}$ for control, A. ornata, and $C$. torquata cores and in the $0-0.5 \mathrm{~cm}$ depth interval for $N$. succinea cores. The maximum bead depth was in the $0-0.5 \mathrm{~cm}$ depth interval in the $C$. torquata and control cores and in the $0.5-1.0 \mathrm{~cm}$ depth interval for A. ornata and $N$. succinea cores.

A Kruskal-Wallis test found the proportion of beads buried in Neanthes succinea and Clymenella torquata cores to be significantly higher than the proportion of beads buried in control cores after $1 \mathrm{~d}$ of burial. There were no significant differences found after $3 \mathrm{~d}$ of burial, but after 7 and $13 \mathrm{~d}$ of burial, respectively, all animal treatments had a significantly higher proportion of beads buried than the control treatment.

\section{DISCUSSION}

The results of this study indicate that Zostera marina seed burial in low organic sandy sediments is facilitated by infaunal bioturbation, and that burial patterns relate, at least in part, to feeding, and thus, bioturbation mode. In addition, burial rates are rapid and occur on a time scale of days. This provides direct support for a mechanism of rapid seed burial and a partial explanation for observed patterns in previous seed dispersal studies, where it was found that seeds do not move far from where they settle on the sediment surface (Orth et al. 1994).

Seed burial depths for Amphitrite ornata, Clymenella torquata, and Pectinaria gouldi related well to individual bioturbation rates for those species, indicating that seed burial was being enhanced by these animals and that seeds were responding as any other large particles in the sediment (de Brouwer et al. 2000). P. gouldi, which buried seeds the most deeply, has the highest bioturbation rate, $6 \mathrm{~g}$ of sediment ind..$^{-1} \mathrm{~d}^{-1}$ (Gordon 1966). The seeds buried most deeply were found near the animal's head, where its feeding activity creates small, continually collapsing feeding voids. Seeds in other areas of the core were much closer to the surface and likely covered by defecated material. A. ornata and C. torquata had similar burial depths, despite representing different feeding modes (upward versus downward conveyors, Kristensen et al. 2012). This was likely due to their similar bioturbation rates, 3.8 and $4.1 \mathrm{~g}$ sediment ind. ${ }^{-1} \mathrm{~d}^{-1}$, respectively (Rhoads 1967). In these cores, there was no significant difference between the mean burial depth of seeds and that of beads, which were both generally buried by being covered with defecated material, though some evidence of $P$. gouldi-like feeding voids was observed in C. torquata cores. This similarity between beads and seeds indicates that both were treated as passive particles. Seeds being buried passively will result in net downward movement, as they are too large for the conveyer belt feeders such as $P$. gouldi or $C$. torquata to ingest (Rhoads 1967) and bring back to the surface. A similar mechanism was identified by Valdemarsen et al. (2011). They reported that Arenicola marina was unable to ingest Zostera marina seeds, but the seeds were buried as a consequence of the conveyor belt feeding behavior of this species

The high proportion of seeds buried in Neanthes succinea cores, and the depths to which those seeds were buried, related poorly to the species' comparably low individual bioturbation rate observed in this experiment. The low proportion of seeds left on the core surface and the number of seeds found in the animals' burrows suggest that $N$. succinea actively take seeds into their burrows. This is supported by the significant difference between mean burial depths of seeds and beads - they were not being passively buried, and the worms had different preferences for seeds and beads. This active burial resulted in rapid seed burial. It is possible that $N$. succinea actively selects particles and rejects less palatable ones such as our beads based on some chemical cue, but we were not able to determine this from our experiment. Delefosse \& Kristensen (2012) also reported a similar mechanism for Nereis diversicolor in Danish waters where seeds were rapidly transported into the animals' burrows.

The rapid burial of Zostera marina seeds is biologically important for several reasons. First, it allows seeds to escape predation by animals foraging on the sediment surface. Second, burial provides a way for a seed to settle into and remain at a site suitable for germination and seedling establishment. Third, burial is required for the seed to reach a region of the sediment that has low oxygen levels, which have been found to be important in initiating germination (Moore et al. 1993). However, burial can also be detrimental if seeds are buried below a threshold depth beyond which the developing cotyledon cannot reach the surface (Greve et al. 2005, Valdemarsen et al. 2011)

Predation is a major risk to seed survival (Janzen 1971). In the Chesapeake Bay, one of the major Zostera marina seed predators is the blue crab Callinectes sapidus. Fishman \& Orth (1996) found that 
$65 \%$ of seeds in field manipulative experiments could be lost to predation by C. sapidus in $7 \mathrm{~d}$, and that burial protected seeds from predation. In our study, we observed significant burial of seeds within days for all species. This burial, even by the slower species, is fast enough to reduce seed predation by C. sapidus.

For seeds undergoing dispersal, settling into and remaining at a suitable germination site (Harper 1977) requires rapid burial. Sediments with infauna provide a mechanism for this burial. All 4 species of infauna were able to bury a large proportion of seeds below the sediment surface in a matter of a few days, and in 1 species, in a matter of hours. We found that Pectinaria gouldi can bury $10 \%$ of nearby seeds in $0.5 \mathrm{~h}$ and $33 \%$ in $3.5 \mathrm{~h}$, with $6.7 \%$ of seeds to below $0.5 \mathrm{~cm}$ (data not shown).

Burial is also critical for Zostera marina seedling establishment because the seeds require hypoxic conditions to germinate (Moore et al. 1993, Probert \& Brenchley 1999) and must be buried to at least $0.5 \mathrm{~cm}$ to achieve low enough oxygen levels to cue germination (Probert \& Brenchley 1999). In addition, the seedlings produced from seeds buried to the depths found here are more likely to survive winter storms which can erode superficial sediments (Marion \& Orth 2012). Over the course of the summer, seeds must be buried below $0.5 \mathrm{~cm}$ in order to germinate and establish as successful seedlings. All 4 species used in this study were able to bury seeds below $0.5 \mathrm{~cm}$ depth over a $2 \mathrm{wk}$ period, and most likely, seed burial would have been even greater if the experimental period had been longer (e.g. months).

Seed burial could also have negative consequences for seedling establishment if seeds are buried too deep. Valdemarsen et al. (2011) found that bioturbation by Arenicola marina had a strong negative effect on the successful establishment of Zostera marina seedlings. However, A. marina was found to rework the top 18 to $20 \mathrm{~cm}$ of sediment, while the infauna used in the present study only rework the top $\sim 10 \mathrm{~cm}$ (Rhoads 1967). It is therefore unlikely that the species in our study have the same negative effect on seedling establishment as does A. marina. $Z$. marina seeds buried below $\sim 5$ to $6 \mathrm{~cm}$ are generally not considered able to successfully germinate (Jarvis \& Moore 2010), but this lower threshold for successful germination depends on sediment type and whether the seed is in an erosional or depositional zone. In sandier sediments and in areas of sediment erosion, deeper burial as recorded with Pectinaria gouldi and Neanthes succinea may be favorable or even necessary for successful seedling establishment.
In the field, infauna are patchily distributed, but the infaunal density used in this study, which corresponds to 127 ind. $\mathrm{m}^{-2}$, is not unrealistic for these species (Dauer et al. 1989, Schaffner 1990), with the exception of Amphitrite ornata, which is generally found at tens of ind. $\mathrm{m}^{-2}$ (N. J. Blackburn pers. obs.). However, densities of Neathes succinea, Clymenella torquata, Pectanaria gouldi, and A. ornata have ranged as high $1000,400,100$, and $57 \mathrm{~m}^{-2}$, respectively (Wass 1972, Orth 1973, R. J. Orth unpubl. data). The burial estimates presented here most likely underestimate the burial occurring at higher densities of infauna. The estimated number of seeds buried by $N$. succinea in the present study is also likely to be low, since individuals usually range more widely than the core allowed and would naturally encounter more seeds. A diverse benthic infaunal community with different types of bioturbators (Kristensen et al. 2012) will also facilitate burial by increasing the topographic complexity of the sediment surface, allowing seeds to be retained near a mound or depression. For infauna like $C$. torquata, seed proximity was very important in determining the likelihood of burial (N. J. Blackburn pers. obs.). Luckenbach \& Orth (1999) reported that seeds entrapped near a $C$. torquata tube frequently became covered by the worms' biodeposits, and that sediment microtopography observed in the field was not only likely caused by deposit-feeding worms but also sufficient to both retain seeds and promote shallow seed burial. For infauna that actively collect seeds such as $N$. succinea, increased seed retention by small-scale sediment features can increase the chance that a seed will be encountered and collected by an individual. Seed entrapment and retention, and the time scale over which it takes seeds to become entrapped, may prove to be important in determining the overall effectiveness of an infaunal community in burying seeds, and will be driven by the microtopography created in part by that community.

The microtopography created by an infaunal community, as well as that community's effectiveness in burying seeds, is also likely to be affected by the strength of currents and waves in that area. Currents that are too weak to move seeds along a flat bottom $\left(<0.7 \mathrm{~m} \mathrm{~s}^{-1}\right.$; Orth et al. 1994) will still be strong enough to transport the unconsolidated sediment ejected into the water column by defecating infauna, which will spread the influence of an individual beyond its still-water defecation mound, but reduce the rate at which it could bury a nearby seed. However, these low-shear currents are not likely to influ- 
ence the efficiency of active burial, as animals will still encounter and collect seeds. Currents or waves that produce enough shear stress to cause seed transport via bedload will have more of an effect on burial. Under those conditions, it is the entrapment of seeds by microtopographic complexities of the sediment surface that will allow seeds to remain in one place long enough to be buried passively or encountered and buried actively.

The seed burial processes found here are analogous to processes described in the terrestrial literature dating back to Darwin (1881), who described the burial of cinders and pieces of lime and marl in pastureland and agricultural fields, and ascribed this burial to the activities of earthworms in the soil. In many forested areas and grasslands, the top several inches of soil can consist entirely of earthworm castings, with earthworms normally depositing castings at a rate of 1.2 to $25.5 \mathrm{t}_{\text {acre }}^{-1} \mathrm{yr}^{-1}$ (Thorp 1949, Wilkinson et al. 2009). While impressive, this is only a few percent of the rate that sediment is processed by the infauna used in this study, which can be calculated from individual bioturbation rates to be around $1600 \mathrm{t}$ of sediment acre $\mathrm{yr}^{-1}$. With such a large volume of sediment being processed in marine systems, it is not surprising that we found burial happening much more rapidly than terrestrial estimates (Westerman et al. 2009, Willems \& Huijsmans 1994). Despite the difference in magnitude between terrestrial and marine seed burial, there was evidence for both active and passive seed burial, both of which occur in terrestrial systems. In the terrestrial literature, the implications of active burial range from influencing seedling distributions on small spatial scales (Warr et al. 1993) to allowing for interspecific seed competition based on an animal's seed preferences (Regnier et al. 2008). Activity by Neanthes succinea and other animals that bury seeds actively may be an important consideration when examining seedling distributions, and the strength of competition between Zostera marina and other seagrasses, in the field.

Zostera marina seed burial is complex, with both biotic and abiotic processes acting in concert to produce the seedling establishment patterns observed in the field. The results of the experiments here, as well as recent work by Valdemarsen et al. (2011) and Delefosse \& Kristensen (2012), suggest that bioturbation by infauna (e.g. active movement of sediment, formation of mounds and holes) may prove to be dominant and needs to be considered in understanding seedling establishment rates and patterns.
Acknowledgements. This work was funded by a Virginia Institute of Marine Science (VIMS) student assistantship. N. J. B. also received financial support from NSF GK-12 (Division of Graduate Education 0840804). We also thank the members of the VIMS SAV lab, especially S. Marion and D. Wilcox, for their help with this research and L. Reynolds and 2 anonymous reviewers for helpful comments that greatly improved this manuscript. This is contribution number 3262 from VIMS.

\section{LITERATURE CITED}

Beck MJ, Vander Wall SB (2010) Seed dispersal by scatterhoarding rodents in arid environments. J Ecol 98: 1300-1309

Benvenuti S (2007) Natural weed seed burial: effect of soil texture, rain and seed characteristics. Seed Sci Res 17: $211-219$

> Chambers JC, MacMahon JA (1994) A day in the life of a seed - movements and fates of seeds and their implications for natural and managed systems. Annu Rev Ecol Syst 25:263-292

Chambers JC, MacMahon JA, Haefner JH (1991) Seed entrapment in alpine ecosystems - effects of particle size and diaspore morphology. Ecology 72:1668-1677

> Chan Y, Walmsley RP (1997) Learning and understanding the Kruskal-Wallis one-way analysis-of-variance-byranks test for differences among three or more independent groups. Phys Ther 77:1755-1762

Chang ER, Veeneklaas RM, Buitenwerf R, Bakker JP, Bouma TJ (2008) To move or not to move: determinants of seed retention in a tidal marsh. Funct Ecol 22:720-727

Darwin C (1881) The formation of vegetable mould through the action of worms with observations of their habits. John Murray, London

Dauer DM, Ewing RM, Ranasinghe JA (1989) Macrobenthic communities of the lower Chesapeake Bay. March 1985-June 1988. Chesapeake Bay Program, Richmond, VA

de Brouwer JFC, Bjelic S, de Deckere E, Stal LJ (2000) Interplay between biology and sedimentology in a mudflat (Biezelingse Ham, Westerschelde, The Netherlands). Cont Shelf Res 20:1159-1177

> Delefosse M, Kristensen E (2012) Burial of Zostera marina seeds in sediment inhabited by three polychaetes: laboratory and field studies. J Sea Res 71:41-49

- Eisenhauer N, Marhan S, Scheu S (2008) Assessment of anecic behavior in selected earthworm species: effects on wheat seed burial, seedling establishment, wheat growth and litter incorporation. Appl Soil Ecol 38:79-82

> Fishman JR, Orth RJ (1996) Effects of predation on Zostera marina L. seed abundance. J Exp Mar Biol Ecol 198: 11-26

Folk RL (1980) Petrology of sedimentary rocks, Hemphill Publishing Company, Austin, TX

Frick H, Rahlfs VW (1998) On power and necessary sample sizes of the Wilcoxon-Mann-Whitney test. Comm Statist Theory Methods 27:2445-2460

Gordon DC Jr (1966) The effects of the deposit feeding polychaete Pectinaria gouldi on the intertidal sediments of Barnstable Harbor. Limnol Oceanogr 11:327-332

Green EP, Short F (2003) World atlas of seagrasses. University of California Press, London

Greve TM, Krause-Jensen D, Rasmussen MB, Christensen 
PB (2005) Means of rapid eelgrass (Zostera marina L.) recolonization in former dieback areas. Aquat Bot 82: 143-156

Harper JL (1977) Population biology of plants. Academic Press, London

Harwell MC, Orth RJ (2001) Influence of a tube-dwelling polychaete on the dispersal of fragmented reproductive shoots of eelgrass. Aquat Bot 70:1-7

Haugaasen JMT, Haugaasen T, Peres CA, Gribel R, Wegge P (2010) Seed dispersal of the Brazil nut tree (Bertholletia excelsa) by scatter-hoarding rodents in a central Amazonian forest. J Trop Ecol 26:251-262

> Hughes L, Westoby M (1992) Fate of seeds adapted for dispersal by ants in Australian sclerophyll vegetation. Ecology 73:1285-1299

Janzen DH (1971) Seed predation by animals. Annu Rev Ecol Syst 2:465-492

$>$ Jarvis JC, Moore KA (2010) The role of seedlings and seed bank viability in the recovery of Chesapeake Bay, USA, Zostera marina populations following a large-scale decline. Hydrobiologia 649:55-68

> Kendrick GA, Waycott M, Carruthers TJB, Cambridge ML and others (2012) The central role of dispersal in the maintenance and persistence of seagrass populations. Bioscience 62:56-65

Koch EW, Ailstock MS, Booth DM, Shafer DJ, Magoun AD (2010) The role of currents and waves in the dispersal of submersed angiosperm seeds and seedlings. Restor Ecol 18:584-595

Kristensen E, Penha-Lopes G, Delefosse M, Valdemarsen T, Quintana CO, Banta GT (2012) What is bioturbation? The need for a precise definition for fauna in aquatic sciences. Mar Ecol Prog Ser 446:285-302

Lengyel S, Gove AD, Latimer AM, Majer JD, Dunn RR (2010) Convergent evolution of seed dispersal by ants, and phylogeny and biogeography in flowering plants: a global survey. Perspect Plant Ecol Evol Syst 12:43-55

Lohrer AM, Thrush SF, Hunt L, Hancock N, Lundquist C (2005) Rapid reworking of subtidal sediments by burrowing spatangoid urchins. J Exp Mar Biol Ecol 321:155-169

Luckenbach MW, Orth RJ (1999) Effects of a deposit-feeding invertebrate on the entrapment of Zostera marina L. seeds. Aquat Bot 62:235-247

Marion SR, Orth RJ (2010) Innovative techniques for largescale seagrass restoration using Zostera marina (eelgrass) seeds. Restor Ecol 18:514-526

- Marion SR, Orth RJ (2012) Seedling establishment in eelgrass: seed burial effects on winter losses of developing seedlings. Mar Ecol Prog Ser 448:197-207

Moore KA, Orth RJ, Nowak JF (1993) Environmental regulation of seed germination in Zostera marina L. (eelgrass) in Chesapeake Bay - effects of light, oxygen, and sediment burial. Aquat Bot 45:79-91

Orth RJ (1973) Benthic infauna of eelgrass, Zostera marina, beds. Chesap Sci 14:258-269

> Orth RJ, van Montfrans J (1987) Utilization of a seagrass meadow and tidal marsh creek by blue crabs Callinectes sapidus. I. Seasonal and annual variations in abundance with emphasis on post-settlement juveniles. Mar Ecol
Prog Ser 41:283-294

Orth RJ, Luckenbach M, Moore KA (1994) Seed dispersal in a marine macrophyte - implications for colonization and restoration. Ecology 75:1927-1939

> Orth RJ, Carruthers TJB, Dennison WC, Duarte CM and others (2006) A global crisis for seagrass ecosystems. Bioscience 56:987-996

> Peng CYJ, Lee KL, Ingersoll GM (2002) An introduction to logistic regression analysis and reporting. J Educ Res 96: $3-14$

Probert RJ, Brenchley JL (1999) The effect of environmental factors on field and laboratory germination in a population of Zostera marina L. from southern England. Seed Sci Res 9:331-339

> Quintana CO, Tang M, Kristensen E (2007) Simultaneous study of particle reworking, irrigation transport and reaction rates in sediment bioturbated by the polychaetes Heteromastus and Marenzelleria. J Exp Mar Biol Ecol 352:392-406

> Regnier E, Harrison SK, Liu J, Schmoll JT, Edwards CA, Arancon N, Holloman C (2008) Impact of an exotic earthworm on seed dispersal of an indigenous US weed. J Appl Ecol 45:1621-1629

Renard D, Schatz B, McKey DB (2010) Ant nest architecture and seed burial depth: implications for seed fate and germination success in a myrmecochorous savanna shrub. Ecoscience 17:194-202

> Rhoads DC (1967) Biogenic reworking of intertidal and subtidal sediments in Barnstable Harbor and Buzzards Bay, Massachusetts. J Geol 75:461-476

Schaffner LC (1990) Small-scale organism distributions and patterns of species diversity: evidence for positive interactions in an estuarine benthic community. Mar Ecol Prog Ser 61:107-117

Thorp J (1949) Effects of certain animals that live in soils. Sci Mon 68:180-191

> Valdemarsen T, Wendelboe K, Egelund JT, Kristensen E, Flindt MR (2011) Burial of seeds and seedlings by the lugworm Arenicola marina hampers eelgrass (Zostera marina) recovery. J Exp Mar Biol Ecol 410:45-52

Vanderreest PJ, Rogaar H (1988) The effect of earthworm activity on the vertical distribution of plant seeds in newly reclaimed polder soils in the Netherlands. Pedobiologia 31:211-218

> Warr SJ, Thompson K, Kent M (1993) Seed banks as a neglected area of biogeographic research - a review of literature and sampling techniques. Prog Phys Geogr 17: 329-347

Wass ML (1972) Checklist of the marine invertebrates of Virginia. Spec Sci Rep No. 24 (3rd rev). Virginia Institute of Marine Science, Gloucester Point, VA

Westerman PR, Dixon PM, Liebman M (2009) Burial rates of surrogate seeds in arable fields. Weed Res 49:142-152

Wilkinson MT, Richards PJ, Humphreys GS (2009) Breaking ground: pedological, geological, and ecological implications of soil bioturbation. Earth Sci Rev 97:257-272

Willems JH, Huijsmans KGA (1994) Vertical seed dispersal by earthworms - a quantitative approach. Ecography $17: 124-130$

Submitted: May 14, 2012; Accepted: October 5, 2012

Proofs received from author(s): January 10, 2013
Editorial responsibility: Christine Paetzold, Oldendorf/Luhe, Germany 